\title{
THE EVOLUTION OF THE RURAL CULTURAL LANDSCAPES IN THE SOUTHERN PART OF BUKOVINA
}

DOI: http://dx.doi.org/10.18509/GBP.2019.55

UDC: 908:930.85(498.3)

\author{
Ana Maria Divisevici ${ }^{1,2}$ \\ ${ }^{1}$ Stefan Cel Mare University, Suceava, Romania \\ ${ }^{2}$ M Eminescu National College, Suceava, Romania
}

\begin{abstract}
Rapid and large- scale changes have occurred in the rural landscapes of Bukovina as a result of the agricultural modifications that have been made in time.

Due to the constant and intense agricultural work the transformation carried out by various ethnic farmers, added new layers to the cultural landscapes and have become an important part of the social construction. Some of the old traditional components of the settlement systems are well preserved, but most have disappeared, the material artefacts or the immaterial testimonies made by the Romanians, the Germans, the Jews, the Polish, the Ukrainians and the Rroma along with other migrants managed to build a complex of new cultural landscapes over the time with unique features.

The notion of rural cultural landscape has developed in accordance with the historical heritage and in connection with the local environmental conditions.

Analyzing various factors and some local social and historical aspects it can be taken into account as the existence of unique cultural elements and at the same time as the threat of cultural landscape possible degradation.
\end{abstract}

Keywords: Bukovina, cultural rural landscape, sacral ladscape

\section{INTRODUCTION}

The cultural landscapes are important components of human life. The cultural landscape it is a result of permanent changes produced by the human society, not just as a sum of geo-factors but a hierarchic organization of the matter in a unique way.

All the places are characterized by unique physical and cultural features that individualize them, their attributes provide them the meaning, the potential and the label. The physical elements of the place are setting up the frame for all the anthropological activities, the humans just adjusting them by living in it, each human activity leaves a mark over the ale components of the environment.[1]The visual mark of the human involvement in nature transformation is represented by the cultural landscape, which exists at different stages of visibility. The cultural landscape in its integrality is formed by components with different functionality, ranked in a certain hierarchy, and in a dimensional distribution as spaces, resulted from the combination of shared structural and functional features.[2] As an integrated part of the cultural landscape, the rural landscape is a subsystem that includes different types of agricultural lands, a subsystem of orchards, a subsystem of farms and a subsystem of forests and vegetation etc. 


\section{STUDY AREA}

Northern Moldavia became part of a province called Galitia after the occupation by the Austro-Hungarian Empire in 1774 and later was named Bukowina Dukedom (or Bucovina in Romanian language). The historical province of Bukovina today is divided between Ukraine and Romania. The rural area presented in this paper is located in the southern part of Bukovina, Suceava County overlapping almost entirely with the southern Bukovina region, having a surface of $8.553,3$ square kilometers. There are 98 villages with a surface of 7.140,8 square kilometers. [3]

\section{METHODOLOGY}

The methods used for this paper have been chosen through the optimization of classical techniques used in the research of cultural landscapes. The observation is the most commonly used, being the optimal method for the research of the state and the functionality of the cultural landscape. The inductive method was used to determine the objects, processes and phenomena produced by the rural landscape and determining the quality and judging their value.

Other techniques used were, the deductive method to determine the essential traits of the objects by explaining particular cases, the method of analysis used to know the components, to obtain data on the structure and dynamics of the objects, the types of land, the processes and the phenomena unfolded in the rural space, as well as the method of synthesis and comparison. Another method with an important role was the bibliographic documentation and accumulation of data.[4][5]

\section{RESULTS AND DISCUSSION}

The rural environment of the Bukovina presents numerous particular traits resulting from cultural, social-historical, political and economic developments accumulated in time.

The Bukovinian rural area is composed of a wide variety of types of rural settlements. The factors involved in landscape evolution and classification of the rural cultural landscapes that have been find for the Bukovina can be grouped into natural and anthropic.

From the category of natural ones were identified the geomorphological traits which are composed by two major units, the Carpathian mountains and the Suceava Plateau with particularities generated by the dynamic aspect of the anticlinal and synclinal associations of the Bucovina Ridges, as well as the presence of the hills and wide valleys. The altitude is another important factor in the arrangement of settlements and in the dynamics of rural landscapes.

Among the natural factors are the climatic conditions, the density of the hydrographic network, the development of river meadows and the varied soils. In the Bukovina (The Beech Land) the vegetation is a major natural factor that has shaped the landscapes image, there is one national parks in the Bukovina historic region, in order to protect the secular forest- The Călimani Mountain National Park. The forest has been an important natural resource which has influenced the functionality of rural area, forest covering $53 \%$ of the country's surface.[6]

Human factors are framed by the historical and political context that manipulated the evolution of the Bukovina in time.

The most relevant factor is the large ethnic diversity as a unique feature of the Bukovina region, in its history there were present 11 distinct ethnic structures. Of these, the 
Romanians, the Ukrainians, the Hutuli, the Germans, the Jews, the Polish, the Roma and the Armenians played an important role in the evolution of the rural cultural landscapes. Other factors were the demographic structure and its temporal variations, the traditions folk and customs, crafts and the elements resulting from human activities. [7] A special role is played by the urban factor through the interconnections with the rural space.

In time the evolution of cultural landscape involves permanent interpretation of the structural and functional transformation, through natural elements removal or cultural elements introduction.

According to the functional criteria the rural settlements of the Bukovina region are identified by: high specificity cultural landscapes developed from a distinct way of natural and anthropogenic elements interaction. In this category are included:

- Agrarian landscape

- Housing and household related to the cultural landscape

- Forestry related to the cultural landscape

- Agro-industrial and industrial cultural landscape

- Transports related to the cultural landscape

- Tourism related to the cultural landscape

- Sacral cultural landscape

Another form used to describe rural landscapes is the habitational infrastructures which reveals the particularities of the Bukovina region includes:

- public buildings

- traditional materials used

- traditional architecture,

- military infrastructure,

- symbolic elements

- folklore and traditions

- historical elements

- national parks, natural reservations

- drifting landscapes

The components included in the agricultural landscapes of The Bukovina region consists in different types of arable land, in total of 179.954 ha, cultivated with various species of plants such as corn, wheat, potato, canola etc. mainly in the plateau area, as for example in Milisauti village located in Suceava river basin.[fig.1-2]

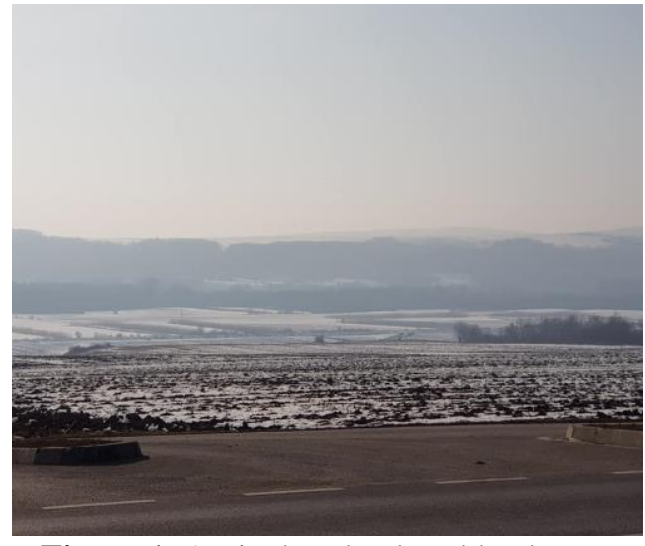

Figure 1. Agricultural cultural landscape in river-plain of Suceava river

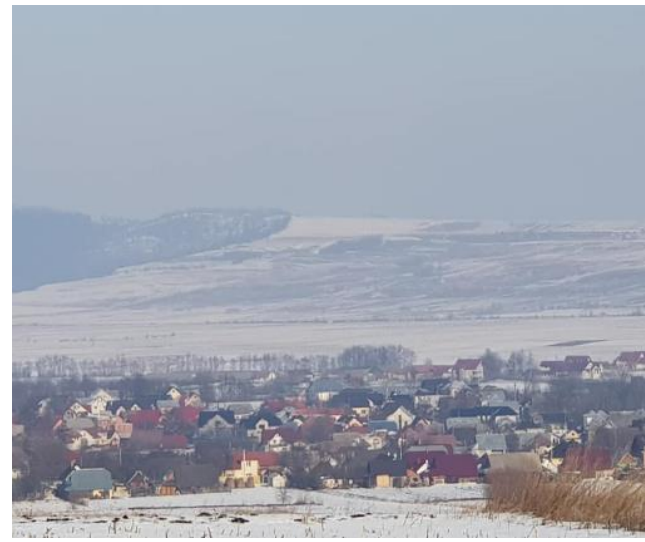

Figure 2. Milisauti village and cultivated field on river-terrace, right side of Suceava river Photo by author 
In the mountain regions the arable fields are reduced in size, but can be identified lands with pastures and hay-fields, [fig.3] different practice of farming such as cattle breeding, and beekeeping. Material culture of Bukovina mountains area underline the anthropogenic features conditioned by people needs and by its practical possibilities of changing the natural elements in the structure of the landscapes.

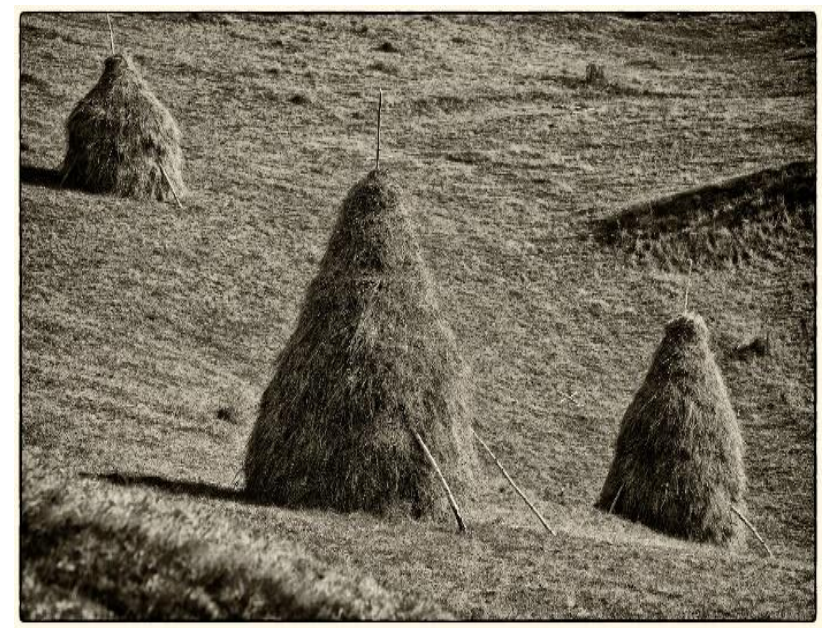

Figure 3. Haystacks-elements of mountain agriculture cultural landscapes Photo by author

In the region of high hills the orchards are the most common presence. Agriculture, no longer perceived in some areas, as a reliable source of income, does not poses a major interest for some local communities and it is more common to find heath fields or uncultivated lands and to aid the development of the drifting landscapes.

The visual expression of human transformation on natural lands, trough housing and household activities, is represented by the traditional household. The traditional components have a central role within the settlement, including elements for people housing, animal housing, tools and cereals storage, water supply etc.

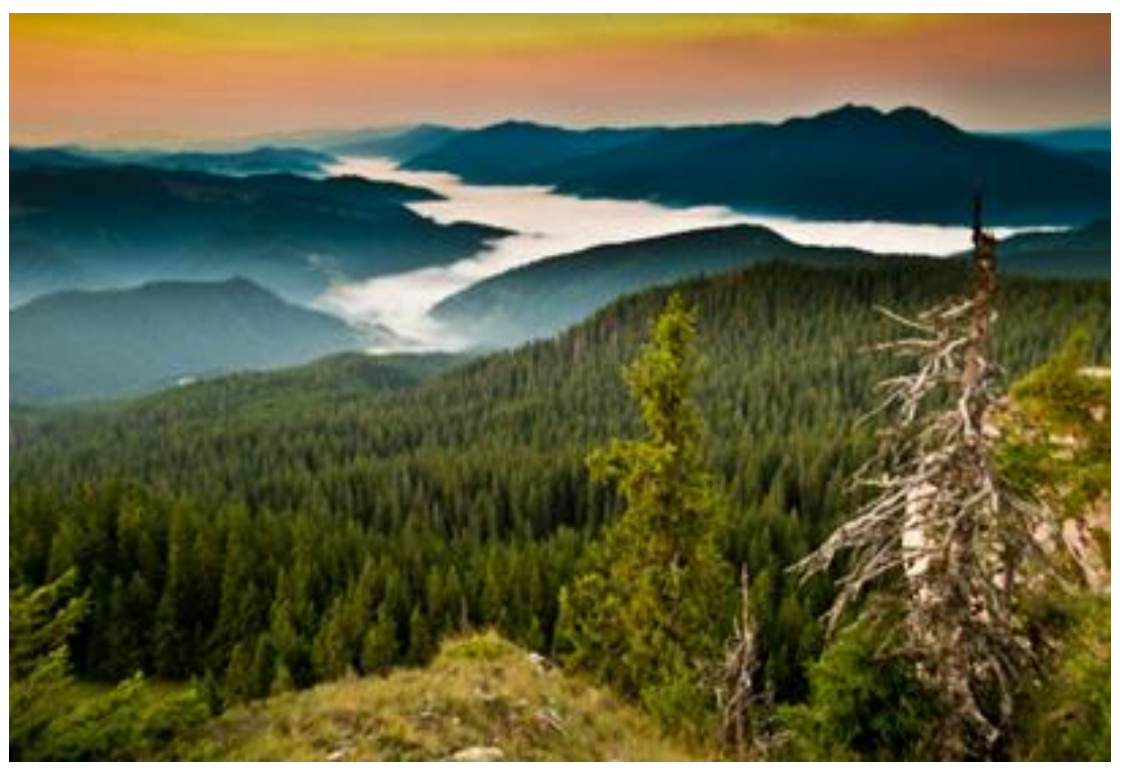

Figure 4. Landscape of coniferus forest

in Rarau Mountain-the southern part of Bukovina photo by the author 
The landscapes related to the forestry emerge from the relation between natural condition and high human intervention on the mountain area, Bukovina being one of the most wooded regions in Romania, with iconic landscapes [fig.4] as the Rarău Mountains.[8] The criterion of the degree of attractiveness has a perceptive connotation, mainly shaped at the mental level, so subjectivity and relativity are often involved in its application. Aesthetic quality is an important assessment criterion derived from the landscapes components, from its structure, architecture and functionality.

Industrial cultural landscapes reside in the existence of mineral resources that led to the development of a 150 years history of mining practice, but nowadays these activities have been stopped. The abandoned industrial constructions generated drifting landscapes due to the economic crisis. A similar unfortunate evolution had the agro-industrial landscapes as for example, the chick industrial farms The Avicola-Burdujeni and The Avicola-Itcani. [fig.5-6]
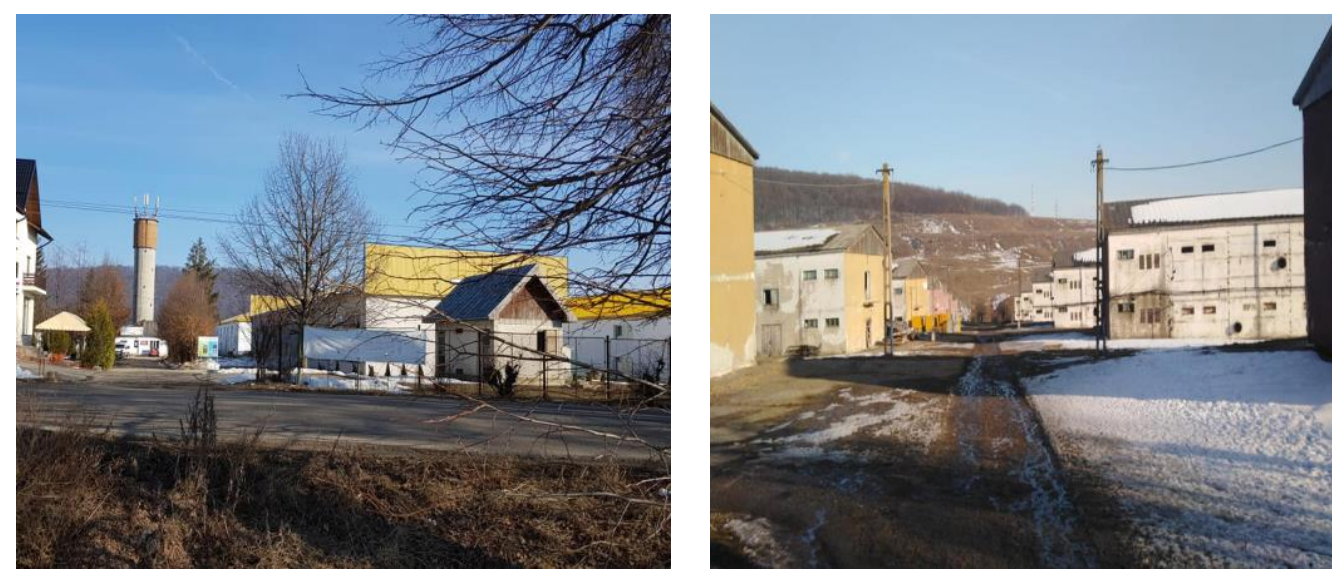

Figure 5, 6. two closed old chick industrial farms: The Avicola -Burdujeni and The Avicola-Itcani, agro-industrial relics, part of drifting landscapes

Photo by author

Analysis of transports related cultural landscapes highlights the presence of three types: road transport, with country-roads with a poor quality in the Rarău Mountains [fig.7] or national lane, rail transport mostly electrified and the traditional rack and pinion trainMocanita and special transport.

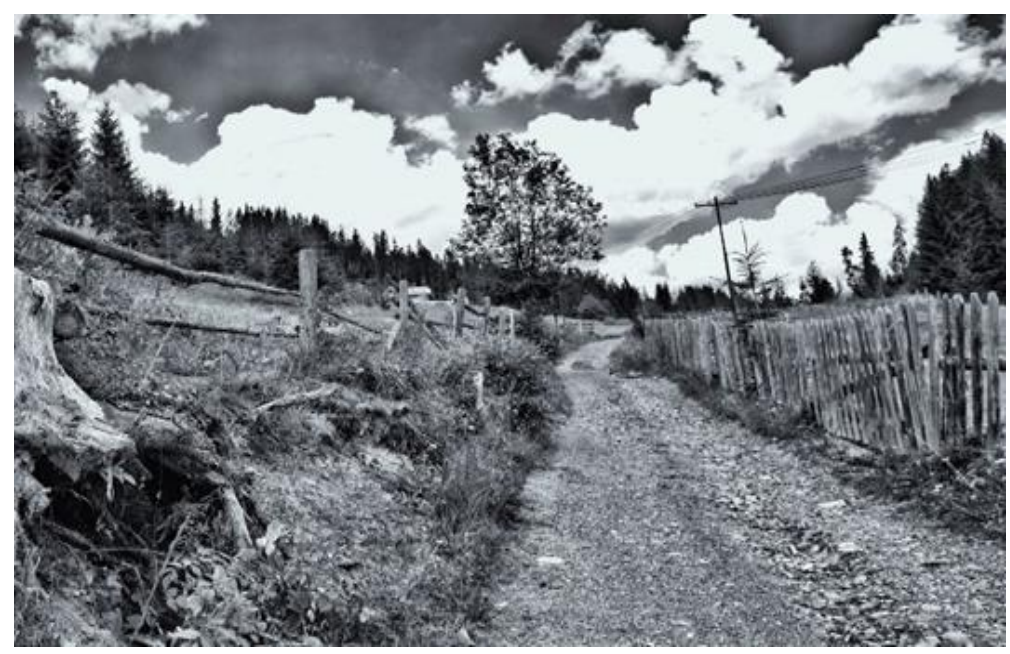

Figure 7. Road in Rarău Mountain

Photo by author 
Cultural landscapes tourism related is well-represented, due to the existence of exquisite anthropogenic elements such as the painted frescoes churches included in UNESCO heritage list, and the presence of natural unique elements. [9]

The most emblematic landscape of all types existing in the Bukovina region, which hides an invaluable cultural treasure, remains the sacral landscapes of the medieval monasteries with the exterior painting.[10]

\section{CONCLUSION}

As a result of past constant changes, induced by natural and human factors action and interaction, the researched area reflects a large variation of rural landscapes, in which the historical cultural elements, stand in perfect harmony with the modern ones.

The inner dynamic futures of Bukovina landscapes will be reflected in the various and different functionality levels determined by habitational tipology, productivity, social, and economic components and carry out by various factors.

The cultural landscapes vulnerability from the south part of the historical region of Bukovina can be evaluated by the physical state of land. The land use is the key activity which determines the performance of landscapes in connection to the socio-economic functions such as land based production housing, infrastructure and traditions. The degree of integration between these socio-economic functions and environmental functions including natural resources protection depends on the patterns and intensities of land use.

\section{REFERENCES}

[1] M. Bjelland, Daniel R Montello,FelmanJ.,Getis A., Getis Judith -Human Geography. Landsapes of Human Activities, 12 edition McGraw -Hill Education, USA, 2013 pp30-45

[2]P. Cocean N. David- Peisaje Culturale-Ed. RISOPRINT, Cluj-Napoca, Romania, 2014, pp.517

[3]Suceava County Council-Bucovina- Little Europe, Editura Lidana, Suceava -Romania 2015,pp3

[4] Dragut L. -Geografia Peisajului, Ed. Presa Universitara Clujeana, Cluj-Napoca, 2000, Romania, pp 34-41

[5] C. I. Gavra- Cultural landscape typology - International Scientific Conference Dezvoltare si Integrare Europeana, Sighetul Marmatiei, Romania, 2009 16-17oct. 2009, pp 3-8

[6] C. Brândus, Al. I. Cristea -Județul Suceava- Seria Judetele României, Editura Academiei Române, București 2013, pp86-88

[7] P. Cocean.- Tarile -Regiuni geografice si spatii mentale, Ed .Presa Universitara Clujeana, Cluj-Napoca, Romania 2011,pp-76-80

[8] C. Rusu -Masivul Rarău studiu de geografie fizică-Editura Academiei Române Bucuresti, 2002, pp45-107

[9] T. Sinigalia, O.Boldura- Medieval Monuments of Bukovina- ACS Publishing, București, 2010, pp20-46, 222

[10] O. Boldura -Pictura murală din nordul Moldovei. Modificări estetice și restaurare, Editura ACS,Bucuresti, 2013, pp 15-22 